\title{
Spinal Cord Injury and Its Future Therapy - A Perspective
}

\author{
Kalaiselvan $\mathbf{E}^{1}$, Maiti $\mathrm{SK}^{* 1}$, Hoque $\mathbf{M}^{1}$, Naveen Kumar ${ }^{1}$, Dinesh $\mathbf{M}^{2}$ and Manikandan $\mathbf{R}^{3}$ \\ ${ }^{1}$ Division of Veterinary Surgery, ICAR-Indian Veterinary Research Institute, Izatnagar-243 122 (UP), India \\ ${ }^{2}$ Division of Pathology, ICAR-Indian Veterinary Research Institute, Izatnagar-243 122 (UP), India \\ ${ }^{3}$ Division of Immunology, ICAR-Indian Veterinary Research Institute, Izatnagar-243 122 (UP), India
}

*Corresponding author: Maiti SK, Division of Veterinary Surgery, ICAR-Indian Veterinary Research Institute,Izatnagar-243 122

(UP), India

\begin{tabular}{|c|c|}
\hline ARTICLE INFO & ABSTRACT \\
\hline Received: 幽 October 31, 2019 & Abbreviations: CNS: Central Nervous System; SCI: Spinal cord injury; CSPGS: Chondroitin \\
\hline Published: 㹃 November 05, 2019 & $\begin{array}{l}\text { Sulphate Proteoglycans, OMGP: Oligodendrocyte Myelin Glycoprotein; MAIS: Myelin } \\
\text { Associated Inhibitory Proteins; NTF: Neurotrophic Factors; PNS: Peripheral Nervous }\end{array}$ \\
\hline
\end{tabular}

Naveen Kumar, Dinesh M, Manikandan R.

Spinal Cord Injury and Its Future Therapy

- A Perspective. Biomed J Sci \& Tech Res

22(3)-2019. BJSTR. MS.ID.003762.

\section{Mini Review}

Human and animal body comprises of various systems. These body physiological functions coordinated and regulated centrally and peripherally by central nervous system and peripheral nervous system respectively. The Central Nervous System (CNS) consists of brain and spinal cord. This nervous system is complicated network of mechanism which is the central processing unit of an entire nervous system. The nervous system is made up of neurons and neuoglias. The neurons are a specialised cell with membrane ability to generating electrical impulses. Neuoglias are an abundant cell type than neuron in CNS which provides more supports for neurons. Our body system knows about the significance of these cells, so only brain and spinal cord are protected by armour cover of cranium and vertebral column. Because limited regenerative capacity of a neuronal cells [1].

The CNS injury is mainly divided into traumatic and nontraumatic. Traumatic CNS is the largest causes of death and disability, leading to suffering by, and costs to, the individual, their family and society [2]. The traumatic spinal cord injury is a result of primary insult of mechanical injury and consequently leads to cascade of secondary injury mechanisms. The manifestation of spinal cord injury is comprising of motor, sensory and autonomic dysfunctions, which dysregulate body homeostasis. The complications are neurogenic shock, changes in cardiovascular haemodynamics, respiratory failure, bladder dyssynergia, muscle spsticity and wasting, anxiety, depression and sexual dysfunction.
Diagnosis of spinal cord injury is appropriate and possible known well with the advancement of diagnostic imaging techniques. There are various therapeutic modalities encountered for treatment of traumatic spinal cord injury. The most of treatment strategies are mainly minimizing the progression of primary injury and preventing secondary injury mechanisms [3].

\section{Spinal Cord Injury (SCI) Incidence}

Spinal cord injury (SCI) regarding in humans, getting an accurate incidence and prevalence is difficult because most of the developing countries not having separate spinal injury trauma unit and lack of national data entry. Recent year's spinal cord injury incidence rapidly increases due to modernisation and rapid industrialisation. Worldwide incidence expected to be 250000500000 cases every year [4]. In developing countries like India road accidents will be most disabling condition by 2020. Wide world the average prevalence of SCI estimated to be 1:1000 and mean incidence proposed to be 4 and 9 cases per one lakh population per year. Spinal cord injury is a globally still incurable medical ailment conditions associated with mild to extreme severe disability of motor-sensory, autonomic functions of the body. Although much development and research activities happening in medical field, neither complete cure of spinal cord regeneration nor restore the physiological functions. So, we need to extend research of preclinical study in order to translate to humans. 


\section{Faithful Model of SCI}

Rat is a faithful animal for neuroscience, behavioural research and regenerative research for preclinical studies. The greater size of rat provides much more advantages than mice especially borne to surgical procedures and in studies of spinal cord injury, where rat models have been higher translational value [5]. It is much easier to handle and less stressed by human approaches than mice [6]. In the recent decades gene based neuroscience research growing with mice but rat and mice show drastic differences in basic studies like cognition, addiction, impulsive, social behaviour and demonstrate differences in extent of neuroregeneration, demonstrating the significance of appropriate model for a human wisely [7], moreover SCI injury changes in rats are similar to humans [8]. Human spinal cord injury much more complex than experimentally produced rat models although anatomical differences of axonal tracts should be taken into account with human, Rat is to be convenient model of spinal injury due to low incidence of surgical affections and wellestablished functional analysis techniques [9].

\section{Type of Spinal Cord Injury Models in Rat}

Still what we know about spinal cord injury pathophysiology mechanism is very little. So to know pathophysiological aspects of spinal cord injury and to evaluate CNS spinal cord regeneration, many model has been created for spinal cord injury related to interest [10], for example weight drop model that first described by Andrew [11], aneurysm clip compression [12], calibrated forceps compression [13], contusion [14], complete transaction model [15], excitotoxic model via chemically mediated [16], tractive model [17], epidural balloon inflation compression model [18], hemitransaction model [19]. This hemi transaction model commonly used to investigate nerve grafting in biomaterials research [20]. This partial transaction model simulates an injury more likely to be seen clinically than complete transaction and provides comparison between injured and healthy fibres in same animals [21]. This model relatively controlled injury environment, low morbidity, and the full transaction or crush injury models. Hence biomaterial scaffold, nerve grafting studies its being good model of choice [22].

\section{Spinal Cord Injury Pathophysiology}

Spinal cord injury is a mechanical insult from externally as a primary injury comprises of various mechanisms and degree of injury with compression, laceration, shearing and distraction followed by cascade of secondary injury from seconds haemorrhage, decreased ATP, lactate acidosis [23]. These in turn neuron inflammation leads to degeneration of neurons by reactive astrocytes and these reactive astrocytes forming a glial scar [24]. Astrocytes are double edged weapon or remedies, earlier days astrocytic glial scar is a major limitation in spinal cord regeneration by inhibitory molecules Chondroitin Sulphate Proteoglycans (CSPGS), but this is not only by astrocytes, other cellular products also [25] in the sense these scar form a boundary to avoid further neuronal damage. But it aids in CNS axon regeneration by expressing multiple axon growth support molecules [26]. Although intrinsic factor of neurons [27] and multiple growth inhibitory molecules limits axonal regeneration, mainly glial scar and Myelin Associated Inhibitory Proteins (MAIs). These MAIs include many notably Myelin Associated Glycoprotein (MAG), Oligodendrocyte Myelin Glycoprotein (OMgp), ephrin-b3, etc [28]. Glial scar containing CSPGs members are neurocan [29], versican v2 [30], brevican [31].

\section{Conventional Therapy In SCI}

Conventionally, clinically methylprednisolone, cox-2 inhibitors, vitamins, calcium channel antagonists, hormones like thyroid releasing hormone, nutritional supplements like selenium, zinc, and magnesium and anti-excitotoxic agents are used [32]. A major focus over years has been on methyl Prednisolone as a therapeutic agent for treatment of SCI in humans. Unfortunately, data available from different clinical trials are controversial and qualitative. In addition to above drug, none of the treatments such as TRH, opioid antagonist and free radical scavengers in preclinical and clinical studies have been proven to be a major advantage in treatment of SCI [33]. In the experimental level, biologically active peptide gamma 1 chain of laminin 1 promotes axonal guidance by neuron outgrowth factors promotion [34], anti-no-go-A blocking agents/antibodies 11c7, 7B12 increase regeneration, plasticity of the lesioned CNS by increasing cellular cAMP [35]. Cethrin is an inhibitor of Rho signalling pathway which is having neuroprotective and neuroregenerative properties [36]. Cordaneurin drug is a scar preventing substance approved for acute spinal cord injury by European Union-2004. Epherin A4 antagonist and apoptosis inhibitors (caspase inhibitors, potassium channel blockers (fampridine), Na channel blockers rizole, phosphor diesterase inhibitors involved in molecular interventional therapy of SCI [32].

\section{Neurotrophins in SCI}

Another approach of SCI therapy is borne to neurotrophins. It is the growth factor form the CNS, promotes the normal development and functional maintenance. Neurotrophins enhance neuronal survival, remyelination, axonal growth [37]. Notably brain derived neuronal factor [38], NT-3 and GDNF are contribute neuron survival with synaptic transmission, axon sprouting and remyelination respectively [39]. Neurotrophic Factors (NTF) having short half-life so exogenous delivery of NTF low efficacy due to blood brain barrier, so cell mediated delivery of NTF will be the ideal [40]. On the other hand, in the neurotrophies group, nerve growth factors also produce detrimental effect like hyperalgesia and chronic pain [41]. The consideration of advantages of neurotrophic factors various studies underwent like implantation of NT soaked gel foam with laminin, fibronectin, NT delivery by mini osmotic pumps [42], injection with recombinant virus mediated gene therapy with NT genes [43]. The disadvantage of neurotrophic is that proneurotrophins binds to p75 NTR receptor and leads to apoptosis of the cell [44]. 


\section{Cell Based Approaches in SCI}

Cell based approaches in SCI mainly by two concepts (1) directly replace the cells lost due to injury (oligodendrocytes or neurons or meningial cells), (2) providing hospital environment in such a way that either enhance or aids axonal regeneration and provide neuroprotection [45]. Schwann cells myelinating glial cells of the Peripheral Nervous System (PNS). Peripheral nerve grafts transplantation is the evidence of Schwann cell support axonal regeneration of CNS neuron [46,47]. The Schwann cell transplants also enhances remyelination and support axon growth [48] but axons do not extend beyond growth permissive graft so the remyelination of spared demyelinated axons and no functionally meaning full synaptic connections [49] leads to doubtful about therapeutic utility of Schwann cell in humans.

Schwann cell transplantation has neither neurological worsening nor improvement [50,51]. Olfactory ensheathing cell is a pluripotent olfactory nerve Schwann cell. This cell supports the axons leaves the olfactory epithelium and project through the PNS into olfactory bulb of CNS [52]. These olfactory unsheathing cells aids in axon regeneration and functional improvement in SCI rats [53]. This OEC does not form myelin [54], but it is creating environment for axonal growth and neurotrophic support $[55,56]$. Although in human study OECs failed to provide significant utilities [57]. Transplantation of olfactory bulb cells has been reported successful in 38-year-old SCI patient [58].

\section{Stem Cell-Based Approaches In SCI}

Stem cells are capable of prolonged self-renewal and having ability to differentiate into multiple cell types [59]. The stem cells in neurological therapy with great concern by its property mainly transplanting cells act as bridge at lesion area and scaffolding for regrowing fibres to rejoin via secreting growth and neurotrophic factors [60]. The stem cells also having neuroprotective ability by secreting certain substances like cytokines, growth factor and trophic factor; the true stem cell is a totipotent. Many researchers considered zygote is a true stem cell because they can differentiate into any cell in favourable medium it can make a whole organism $[61,62]$. Other than zygote, stem cells broadly taxonomized into two types-one is somatic stem cells which is undifferentiated cells among the differentiated cells of specific tissue population after birth [59] second one is Embryonic Stem Cells (ESCs) which is in the inner cell mass of blastocyst [63]. In spinal cord injury, engrafting of ESC-derived stem cell is a strategy with a unique property of stem cell especially appropriate combination of growth factors; it can be used to obtain neurons and glial cells [64]. As stated, earlier demyelination of an intact axon is a major sequence of SCI [65]. Remyelination is needed for locomotor improvement and restore the salutatory conduction of neuron [66].

Notably human embryonic stem cell derived oligodendrocytes progenitor cells transplant remyelination and restore locomotion after spinal cord injury [67]. The problem of ESC derived immature lineage cells is ability to induce teratoma after transplantation [68]. But with the high purity production of ESC derived cells it can limits the tumour inducing potential of ESC [69]. Neural Stem Cells (NSC) are multipotent, having ability to produce complete neural lineages [45]. The NSC is a remnant of neuroectoderm present in the brain and spinal cord. In adult the source of NSC cell is Sub Ventricular Zone (SVZ) lining the lateral ventricles and the Subgranular Zone (SGZ) within the Dentate Gyrus (DG) of the hippocampus and spinal cord [70], These NSC contributes the remyelination [71] and inturn improves axonal conduction. In a different study on human neural stem cell transplants is found effective for SCI in primates [72] the limitation of NSC is that obtaining cells [73]. Other approach is to stimulate endogenous NSC, but in vivo microenvironment not good to stimulate NSC regeneration [74]. Although ESC derived NSC/NPC is an exogenous source, obtaining high purity is a mater.

Another type of somatic stem cell widely studied is mesenchymal stem cells. There are various sources for mesenchymal stem cells likely Wharton jelly of umbilical cord [75], bone marrow derived mesenchymal stem cells [76] and Dental pulp [77]. Human Dental Pulp Derived Stem Cells (DPSCs) having neuroprotective, neroregenerative, neurotrophic support in preclinical study [78]. This neural crest originated DPSCs could be an ideal stem cell candidate for treating neurological and neurodegenerative diseases [79]. Although, no reports of clinical study in human spinal cord injury, transplantation of human immature dental pulp in spinal injured dogs showed improvement [80]. So many things have to take into account required stem cell density and availability, desirable strategies, for their use. For example, DPSCs or exfoliated deciduous tooth stem cells are not available throughout a patient's lifetime. Stem cell banking can overcome that, it is time-consuming and costly limits their use in clinical applications [81]. Human umbilical cord blood and Wharton's jelly isolated MSC transplantation reduces neuropathic pain [19] and improved sensory recovery [82] of SCI in rats.

The limitation of human UC blood isolated MSC is maternal cell contamination which negatively influence the utilization of this material for cell-based therapy due to Graft-Versus Host Disease (GVHD) [83]. Adipose tissue derived mesenchymal stem cells are easily can harvest from abundant adipose tissue [84]. These MSC secretes neurotrophic factor [85] which aids neuroprotection in ischemic spinal cord injury [86]. Bone marrow derived mesenchymal stem cell is a currently widely using MSC in spinal cord injury and regeneration due to its wide variety of study reports [87]. It lacks tumorogenic potential [88], neuroprotective ability [89] through expression of various kinds mRNA related to neurotrophic factors [90], immunosuppressive by low expression of MHC antiinflammatory, aiding in axonal regeneration, endogenous stem cell activating property [91] unlike ESC no ethical problem and induce remyelination [92]. The BMSC administration is safe and feasible [93]. The limitation of MSC is that it needs substrate to attach which will improve survivability because anchorage dependant property 
[94]. Hence MSC with scaffold increase survivability and overcome above stated limitation.

\section{Stem Cells \& Nerve Growth Factors (NGF)}

Another approach is stem cell and NGF. Advantage of this approach is that the stem cell secretes certain neurotrophic factors which are substantial neuronal recovery from spinal cord injury. Exogenous neurotrophic factor or over expressing NGF secreting cells are adding stem cell survivability $[95,96]$ and helps in endogenous protective mechanism [97]. MSCs and NGF synergistic effect in promote axonal regeneration and improve functional recovery [98]. Limitation of this approach is that the injury site is not hospital environment for stem cell survival and attachment because injury site ECM related molecules and pathological state hampers advantage of this approach although various studies with significant results.

\section{Biomaterial \& Stem Cells + Nerve Growth Factors}

Biological scaffold materials composed of Extra Cellular Matrix (ECM) which assists the constructive remodelling of many different tissues in both preclinical animal studies and in human clinical applications. The composition of the biological scaffolds consists of a complex mixture and paternally arranged molecules in unique three-dimensional (3-D that mediate structural and/ or biological properties patterns. So, it's an ideally suited to the tissue from which the ECM is harvested [99]. For example, acellular sciatic nerve scaffold in spinal injury favours environment for axon regeneration, but alone showing insufficient axon regeneration and low locomotor recovery combination with BDNF showing benefits [100]. Notably acellular spinal cord seeded with mesenchymal stem cell improves robust long-distance axonal regeneration in spinal cord injured rodent study [101].

\section{Conclusion}

The spinal cord injury is a very complex mechanism so simply targeting a single mechanism does not give a good translational value. To improve the therapeutic strategies in spinal cord injury making lesion site like in vivo or mimic like environment by tissue engineering technology is focusing area. So the optimal multidisciplinary approach combining biomaterials, stem cells, and bio molecules offers a promising treatment for repairing the injured spinal cord [102]. From above review lack of combined therapeutic strategy are noticed regarding spinal cord injury strategy. Hence to fill the limitation, we hypothesis that the nerve growth factor enriched spinal cord tissue derived hydrogels combined with Stem Cell Therapy (MSC) may be good approach in treatment of spinal cord injury.

\section{References}

1. Steward MM, Sridhar A, Meyer JS (2013) Neural regeneration. Curr Top Microbiol Immunol 367: 163-191.

2. Rubiano AM, Carney N, Chesnut R, Puyana JC (2015) Global neurotrauma research challenges and opportunities Nature 527(7578): S193.
3. Markandaya M, Deborah M Menaker S (2012) Acute Treatment Options for Spinal Cord Injury. Current Treatment Options in Neurology.

4. Singh R, Yadav S, Meena V (2017) Community reintegration postspinal cord injury: Indian scenario. Journal of Orthopaedics and Allied Sciences 5(1): $15-20$

5. Kjell J, Olson L (2016) Rat models of spinal cord injury: from pathology to potential therapies. Disease models \& mechanisms 9(10): 1125-1137.

6. Meijer MK, Sommer R, Spruijt BM, Van Zutphen LFM, Baumans V (2007) Influence of environmental enrichment and handling on the acute stress response in individually housed mice. Laboratory animals 41(2): 161173.

7. Ellenbroek B, Youn J (2016) Rodent models in neuroscience research: is it a rat race? Disease models \& mechanisms 9(10): 1079-1087.

8. Fleming JC, Norenberg MD, Ramsay DA, Dekaban GA, Marcillo AE, et al. (2006) The cellular inflammatory response in human spinal cords after injury Brain 129(12): 3249-3269.

9. Lukovic D, Moreno Manzano V, Lopez Mocholi E, Rodriguez Jimenez FJ, Jendelova P, et al. (2015) Complete rat spinal cord transection as a faithful model of spinal cord injury for translational cell transplantation. Scientific reports 5: 9640 .

10. Onifer SM, Rabchevsky AG, Scheff SW (2007) Rat models of traumatic spinal cord injury to assess motor recovery. ILAR journal 48(4): 385395.

11. Andrew RB (1996) An overview of spinal cord injury models. In: Povlishock JT, Neurotrauma. McGraw-Hill, New York, USA, pp. 13671379.

12. Von Euler M, Seiger Å, Sundström E (1997) Clip compression injury in the spinal cord: a correlative study of neurological and morphological alterations. Experimental neurology 145(2): 502-510.

13. Gruner JA, Yee AK, Blight AR (1996) Histological and functional evaluation of experimental spinal cord injury: evidence of a stepwise response to graded compression. Brain research 729(1): 90-101.

14.Cao Q, Zhang YP, Iannotti C, De Vries WH (2005) Functional and electrophysiological changes after graded traumatic spinal cord injury in adult rat. Experimental neurology 191: S3-S16.

15. Woerly S, Sosa N, De Vellis J, Espinosa A (2001) Reconstruction of the transected cat spinal cord following NeuroGel ${ }^{\mathrm{TM}}$ implantation: axonal tracing immunohistochemical and ultrastructural studies. International Journal of Developmental Neuroscience 19(1): 63-83.

16. Sairazi M, Shafika N, Sirajudeen KNS, Asari MA, Muzaimi M, et al. (2015) Kainic acid-induced excitotoxicity experimental model: protective merits of natural products and plant extracts. Evidence-Based Complementary and Alternative Medicine.

17. Wang W, Yang T, Lei M, Pei F, Liu L (2011) Establishment of tractive spinal cord injury model in rats with a novel spinal distractor.

18. Vanický I, Urdzíková L, Saganová K, Čízková D, Gálik J (2001) A simple and reproducible model of spinal cord injury induced by epidural balloon inflation in the rat. Journal of neurotrauma 18(12): 1399-1407.

19. Takikawa S, Yamamoto A, Sakai K, Shohara R, Iwase A (2013) Human umbilical cord-derived mesenchymal stromal cells promote sensory recovery in a spinal cord injury rat model. Stem Cell Discov 3(3): 155163.

20. Alilain WJ, Horn KP, Hu H, Dick TE, SilverJ (2011) Functional regeneration of respiratory pathways after spinal cord injury. Nature 475(7355): 196.

21. Cheriyan T, Ryan DJ, Weinreb JH, Cheriyan J, Paul JC, et al. (2014) Spinal cord injury models: a review. Spinal cord 52(8): 588.

22. Kushchayev SV, Giers MB, Eng DH, Martirosyan NL, Eschbacher JM, et al. (2016) Hyaluronic acid scaffold has a neuroprotective effect in hemisection spinal cord injury. Journal of Neurosurgery: Spine 25(1): 114-124. 
23. Ahuja CS, Martin AR, Fehlings M (2016) Recent advances in managing a spinal cord injury secondary to trauma. F1000Research: 5.

24. Yuan Yi Min, Cheng He (2013) The glial scar in spinal cord injury and repair. Neuroscience bulletin 4: 421-435.

25. Morgenstern DA, Asher RA, Fawcett JW (2002) Chondroitin sulphate proteoglycans in the CNS injury response. Prog Brain Res 137: 313-332.

26. Anderson MA, Burda JE, Ren Y, Ao Y, OShea TM, et al. (2016) Astrocyte scar formation aids central nervous system axon regeneration.Nature 532(7598): 195.

27. Cai D, Qiu J, Cao Z, Mc Atee M, Bregman BS, et al. (2001) Neuronal cyclic AMP controls the developmental loss in ability of axons to regenerate. Journal of Neuroscience, 21(13): 4731-4739.

28. Huebner EA, Strittmatter SM (2009) Axon regeneration in the peripheral and central nervous systems. InCell biology of the axon (pp. 305-360). Springer, Berlin, Heidelberg.

29. Asher RA, Morgenstern DA, Fidler PS, Adcock KH, Oohira A, et al. (2000) Neurocan is upregulated in injured brain and in cytokine-treated astrocytes. Journal of Neuroscience, 20(7): 2427-2438.

30. Schmalfeldt M, Bandtlow CE, Dours Zimmermann MT, Winterhalter KH Zimmermann DR (2000) Brain derived versican V2 is a potent inhibitor of axonal growth. J Cell Sci, 113(5): 807-816.

31. Yamada H, Fredette B, Shitara K, Hagihara K, Miura R, et al. (1997) The brain chondroitin sulfate proteoglycan brevican associates with astrocytes ensheathing cerebellar glomeruli and inhibits neurite outgrowth from granule neurons. Journal of Neuroscience, 17(20), 7784-7795.

32. Onose G, Anghelescu A, Muresanu DF, Padure L, Haras MA, et al. (2009) A review of published reports on neuroprotection in spinal cord injury. Spinal Cord 47(10): 716.

33. Samantaray S, Sribnick EA, Das A, Thakore NP, Matzelle D, et al. (2010) Neuroprotective efficacy of estrogen in experimental spinal cord injury in rats. Annals of the New York Academy of Sciences 1199: 90.

34. Liesi P, Laatikainen T, Wright JM (2001) Biologically active sequence (KDI) mediates the neurite outgrowth function of the gamma- 1 chain of laminin-1. Journal of neuroscience Research 66 (6): 1047-1053.

35. Buchli AD, Schwab ME (2005) Inhibition of Nogo: a key strategy to increase regeneration, plasticity and functional recovery of the lesioned central nervous system. Annals of medicine 37(8): 556-567.

36. Mc Kerracher L, Winton M (2006) Targeting Rho to stimulate repair after spinal cord injury. Topics in Spinal Cord Injury Rehabilitation 8(4): 69-75.

37. Kelamangalath L, Smith GM (2013) Neurotrophin treatment to promote regeneration after traumatic CNS injury.Frontiers in biology 8(5): 486495.

38. Kovalchuk Y, Holthoff K, Konnerth A (2004) Neurotrophin action on a rapid timescale. Current opinion in neurobiology 14(5): 558-563.

39. Zhang H, Wu F, Kong X, Yang J, Chen H, et al. (2014) Nerve growth factor improves functional recovery by inhibiting endoplasmic reticulum stress-induced neuronal apoptosis in rats with spinal cord injury. Journal of translational medicine, 12(1): 130.

40. Razavi S, Ghasemi N, Mardani M, Salehi H (2017) Remyelination improvement after neurotrophic factors secreting cells transplantation in rat spinal cord injury. Iranian journal of basic medical sciences 20(4): 392.

41. Romero MI, Rangappa N, Garry MG, Smith GM (2001) Functional regeneration of chronically injured sensory afferents into adult spinal cord after neurotrophin gene therapy. Journal of Neuroscience 21(21): 8408-8416.

42. Deumens R, Koopmans GC, Joosten EA (2005) Regeneration of descending axon tracts after spinal cord injury. Progress in neurobiology 77(1-2): 57-89.
43. Onifer SM, Smith GM, Fouad K (2011) Plasticity after spinal cord injury: relevance to recovery and approaches to facilitate it. Neurotherapeutics 8(2): 283-293.

44. Friedman WJ (2010) Proneurotrophins, seizures, and neuronal apoptosis. The Neuroscientist, 16(3): 244-252.

45. Rowland JW, Hawryluk GW, Kwon B, Fehlings MG (2008) Current status of acute spinal cord injury pathophysiology and emerging therapies: promise on the horizon. Neurosurgical focus 25(5): E2.

46. David S, Aguayo AJ (1981) Axonal elongation into peripheral nervous system "bridges" after central nervous system injury in adult rats. Science 214(4523): 931-933.

47. David S, Aguayo AJ (1985) Axonal regeneration after crush injury of rat central nervous system fibres innervating peripheral nerve grafts. Journal of neurocytology 14(1): 1-12.

48. Pearse DD, Sanchez AR, Pereira FC, Andrade CM, Puzis R, et al. (2007) Transplantation of Schwann cells and/or olfactory ensheathing glia into the contused spinal cord: Survival, migration, axon association, and functional recovery. Glia 55(9): 976-1000.

49. Pinzon A, Calancie B, Oudega M, Noga BR (2001) Conduction of impulses by axons regenerated in a Schwann cell graft in the transected adult rat thoracic spinal cord.Journal of neuroscience research, 64(5): 533-541.

50. Saberi H, Moshayedi P, Aghayan HR, Arjmand B, Hosseini SK, et al. (2008) Treatment of chronic thoracic spinal cord injury patients with autologous Schwann cell transplantation: an interim report on safety considerations and possible outcomes. Neurosci Lett 443(1): 46-50

51. Saberi H, Firouzi M, Habibi Z, Moshayedi P, Aghayan HR, et al. (2011) Safety of intramedullary Schwann cell transplantation for postrehabilitation spinal cord injuries: 2-year follow-up of 33 cases. Journal of Neurosurgery: Spine 15(5): 515-525.

52. Imaizumi T, Lankford KL, Burton WV, Fodor WL, Kocsis JD (2000) Xenotransplantation of transgenic pig olfactory ensheathing cells promotes axonal regeneration in rat spinal cord. Nature biotechnology 18(9): 949.

53. Ramón Cueto A, Cordero MI, Santos Benito FF, Avila J (2000) Functional recovery of paraplegic rats and motor axon regeneration in their spinal cords by olfactory ensheathing glia. Neuron 25(2): 425-435

54. Boyd JD, Doucette R, Kawaja MD (2005) Defining the role of olfactory ensheathing cells in facilitating axon remyelination following damage to the spinal cord. The FASEB journal, 19(7): 694-703.

55. Lipson AC, Widenfalk J, Lindqvist E, Ebendal T, Olson L (2003) Neurotrophic properties of olfactory ensheathing glia. Experimental neurology 180(2): 167-171

56. Richter MW, Roskams AJ (2008) Olfactory ensheathing cell transplantation following spinal cord injury: hype or hope? Experimental neurology, 209(2): 353- 367.

57. Lu P, Yang H, Culbertson M, Graham L, Roskams AJ, et al. (2006) Olfactory ensheathing cells do not exhibit unique migratory or axonal growthpromoting properties after spinal cord injury. Journal of Neuroscience 26(43): 11120-11130.

58. Tabakow P, Raisman G, Fortuna W, Czyz M, Huber J, et al. (2014) Functional regeneration of supraspinal connections in a patient with transected spinal cord following transplantation of bulbar olfactory ensheathing cells with peripheral nerve bridging. Cell transplantation, 23(12): 1631-1655.

59. Ritfeld GJ, Roos RA, Oudega M (2011) Stem cells for central nervous system repair and rehabilitation. PM\&R 3(6): S117-S122.

60. Tetzlaff W, Okon EB, Karimi Abdolrezaee S, Hill CE, Sparling JS, et al. (2011) A systematic review of cellular transplantation therapies for spinal cord injury. J Neurotrauma 28(8): 1611-1682.

61. Nagy A, Rossant J, Nagy R, Abramow Newerly W, Roder JC (1993) Derivation of completely cell culture-derived mice from early-passage 
embryonic stem cells. Proceedings of the National Academy of Sciences 90(18): 8424-8428.

62. Nandoe TRS, Hurtado A, Bartels RH, Grotenhuis A, Oudega M (2009) Stem cell- based therapies for spinal cord injury. The journal of spinal cord medicine 32(2): 105-114.

63. OLeary MA, Bloch JI, Flynn JJ, Gaudin TJ, Giallombardo A, et al. (2013) The placental mammal ancestor and the post-K-Pg radiation of placentals. Science 339(6120): 662-667.

64. Billon N, Jolicoeur C, Ying QL, Smith A, Raff M (2002) Normal timing of oligodendrocyte development from genetically engineered, lineageselectable mouse ES cells.Journal of cell science 115(18): 3657-3665.

65. Totoiu MO, Keirstead HS (2005) Spinal cord injury is accompanied by chronic progressive demyelination. Journal of Comparative Neurology 486(4): 373-383

66. Jeffery ND, Crang AJ, O’leary MT, Hodge SJ, Blakemore WF (1999) Behavioural consequences of oligodendrocyte progenitor cell transplantation into experimental demyelinating lesions in the rat spinal cord.European Journal of Neuroscience 11(5): 1508-1514.

67. Keirstead HS, Nistor G, Bernal G, Totoiu M, Cloutier F, et al. (2005) Human embryonic stem cell-derived oligodendrocyte progenitor cell transplants remyelinate and restore locomotion after spinal cord injury. J Neurosci 25(19): 4694-705.

68. Werbowetski Ogilvie TE, Bossé M, Stewart M, Schnerch A, Ramos Mejia $\mathrm{V}$, et al. (2009) Characterization of human embryonic stem cells with features of neoplastic progression. Nature biotechnology 27(1): 91.

69. Adeeb N, Deep A, Hose N, Rezaei M, Fard SA, et al. (2015) Stem cell therapy for spinal cord injury: The use of oligodendrocytes and motor neurons derived from human embryonic stem cells.Translational Research in Anatomy 1: 17-24.

70. Takagi Y (2016) History of neural stem cell research and its clinical application. Neurologia medico-chirurgica 56(3): 110-124.

71. Yasuda A, Tsuji O, Shibata S, Nori S, Takano M (2011) Significance of remyelination by neural stem/progenitor cells transplanted into the injured spinal cord. Stem Cells 29(12): 1983-1994.

72. Iwanami A, Kaneko S, Nakamura M, Kanemura Y, Mori H, et al. (2005) Transplantation of human neural stem cells for spinal cord injury in primates.Journal of neuroscience research 80(2): 182-190.

73. Salewski RP, Mitchell RA, Shen C, Fehlings MG (2014) Transplantation of neural stem cells clonally derived from embryonic stem cells promotes recovery after murine spinal cord injury. Stem cells and development 24(1): 36-50

74. Grégoire CA, Goldenstein BL, Floriddia EM, Barnabé Heider F (2015) Endogenous neural stem cell responses to stroke and spinal cord injury. Glia 63(8): 1469-1482.

75. Wang HS, Hung SC, Peng ST, Huang CC, Wei HM, et al. (2004) Mesenchyma stem cells in the Wharton's jelly of the human umbilical cord. Stem cells 22(7): 1330-1337.

76. Maiti SK, Shiva Kumar MU, Lucky S, N Kumar, Ninu AR (2012) Isolation, proliferation and morphological characteristics of bone marrow derived mesenchymal stem cells (BM-MSC) from different animal species. Trends in Biomaterials \& Artificial Organs 27: 29-35.

77. Potdar PD, Jethmalani YD (2015) Human dental pulp stem cells: Applications in future regenerative medicine. World journal of stem cells 7(5): 839.

78. Sakai K, Yamamoto A, Matsubara K, Nakamura S, Naruse M, et al. (2012) Human dental pulp-derived stem cells promote locomotor recovery after complete transection of the rat spinal cord by multiple neuroregenerative mechanisms. The Journal of clinical investigation 122(1): 80-90.

79. Shamir C, Venugopal C, Dhanushkodi A (2015) Dental pulp stem cells for treating neurodegenerative diseases. Neural regeneration research 10(12): 1910.
80. Feitosa MLT, Sarmento CAP, Bocabello RZ, Beltrão Braga PCB, Pignatari GC, et al. (2017) Transplantation of human immature dental pulp stem cell in dogs with chronic spinal cord injury.Acta cirurgica brasileira 32(7): 540-549.

81. Chalisserry EP, Nam SY, Park SH, Anil S (2017) Therapeutic potential of dental stem cells. Journal of tissue engineering 8: 2041731417702531.

82. Yang CC, Shih YH, Ko MH, Hsu SY, Cheng H, et al. (2008) Transplantation of human umbilical mesenchymal stem cells from Wharton's jelly after complete transection of the rat spinal cord. PloS one 3(10): e3336.

83. Clifton VL, Stark MJ, Osei Kumah A, Hodyl NA (2012) The feto-placental unit, pregnancy pathology and impact on long term maternal health. Placenta 33: S37- S41.

84.Zuk PA, Zhu M, Ashjian P, De Ugarte DA, Huang JI, et al. (2002). Human adipose tissue is a source of multipotent stem cells. Molecular biology of the cell 13(12): 4279-4295.

85. Lattanzi W, Geloso MC, Saulnier N, Giannetti S, Puglisi MA, et al. (2011) Neurotrophic features of human adipose tissue-derived stromal cells: in vitro and in vivo studies. BioMed Research International p. 1-9

86.Xiao N, Le QT (2016) Neurotrophic factors and their potential applications in tissue regeneration. Archivum immunologiae et therapiae experimentalis 64(2): 89-99.

87. Wright KT, Masri WE, Osman A, Chowdhury J, Johnson WE (2011) Concise review: bone marrow for the treatment of spinal cord injury: mechanisms and clinical applications. Stem cells 29(2): 169-178.

88. Abrams MB, Dominguez C, Pernold K, Reger R, Wiesenfeld Hallin Z, et al. (2009) Multipotent mesenchymal stromal cells attenuate chronic inflammation and injury-induced sensitivity to mechanical stimuli in experimental spinal cord injury. Restorative neurology and neuroscience 27(4): 307-321.

89. Novikova LN, Brohlin M, Kingham PJ, Novikov LN, Wiberg M (2011) Neuroprotective and growth-promoting effects of bone marrow stromal cells after cervical spinal cord injury in adult rats. Cytotherapy 13(7): 873-887.

90. Yamaguchi S, Kuroda S, Kobayashi H, Shichinohe H, Yano S, et al. (2006) The effects of neuronal induction on gene expression profile in bone marrow stromal cells (BMSC)-a preliminary study using microarray analysis. Brain research 1087(1): 15-27.

91. Neirinckx V, Cantinieaux D, Coste C, Rogister B, Franzen R, et al. (2014) Concise review: Spinal cord injuries: how could adult mesenchymal and neural crest stem cells take up the challenge? Stem Cells 32(4): 829-843.

92. Akiyama Y, Radtke C, Kocsis JD (2002) Remyelination of the rat spinal cord by transplantation of identified bone marrow stromal cells. Journal of Neuroscience 22(15): 6623-6630.

93. Chhabra HS, Sarda K, Arora M, Sharawat R, Singh V, et al. (2016) Autologous bone marrow cell transplantation in acute spinal cord injury-an Indian pilot study. Spinal Cord 54(1): 57.

94. Prowse AB, Chong F, Gray PP, Munro TP (2011) Stem cell integrins: implications for ex-vivo culture and cellular therapies. Stem cell research 6(1): 1-12.

95. Sun Y, Shi J, Lu PH (2002) Neurotrophic factors and neural stem cells. Sheng li ke xue jin zhan [Progress in physiology] 33(4): 313-316.

96. Rodrigues M, Griffith LG, Wells A (2010) Growth factor regulation of proliferation and survival of multipotential stromal cells. Stem cell research \& therapy 1(4): 32.

97. Ernsberger U (2009) Role of neurotrophin signalling in the differentiation of neurons from dorsal root ganglia and sympathetic ganglia. Cell and tissue research 336(3): 349-384

98. Huang F, Junfang W, Anmin C (2006) Effects of co-grafts mesenchymal stem cells and nerve growth factor suspension in the repair of spinal cord injury. Journal of Huazhong University of Science and Technology [Medical Sciences] 26(2): 206. 
99. Badylak SF, Freytes DO, Gilbert TW (2009) Extracellular matrix as a biological scaffold material: structure and function. Acta biomaterialia 5(1): 1-13.

100. Li C, Zhang X, Cao R, Yu B, Liang H, et al. (2012) Allografts of the acellular sciatic nerve and brain-derived neurotrophic factor repair spinal cord injury in adult rats. PloS one 7(8): e42813.

ISSN: 2574-1241

DOI: $10.26717 /$ BJSTR.2019.22.003762

Maiti SK. Biomed J Sci \& Tech Res

(C) (P) This work is licensed under Creative

Submission Link: https://biomedres.us/submit-manuscript.php
101. Liu J, Chen J, Liu B, Yang C, Xie D, et al. (2013) Acellular spinal cord scaffold seeded with mesenchymal stem cells promotes long-distance axon regeneration and functional recovery in spinal cord i $\mathrm{n} \mathrm{j} \mathrm{u} \mathrm{r} \mathrm{e} \mathrm{d}$ rats. Journal of the neurological sciences 325(1-2): 127-136.

102. Shrestha B, Coykendall K, Li Y, Moon A, Priyadarshani P, et al. (2014) Repair of injured spinal cord using biomaterial scaffolds and stem cells. Stem cell research \& therapy 5(4): 91.

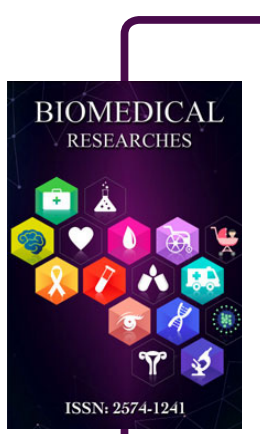

Assets of Publishing with us

- Global archiving of articles

- Immediate, unrestricted online access

- Rigorous Peer Review Process

- Authors Retain Copyrights

- Unique DOI for all articles

https://biomedres.us/ 